\title{
Biochemical and antioxidant effect of Doxorubicin hydrochloride and Propolis on N-methyl-N- nitrosourea (MNU) Induced Adenocarcinoma in Rats
}

\author{
Mohamed 0.T. BADR ${ }^{1}$, Nariman M.M. EDREES ${ }^{1}$, Amany A.M. ABDALLAH ${ }^{1}$, \\ Mohamed A. HASHEM ${ }^{1}$, Nasr A.M.N. EL-DEEN ${ }^{1}$, Ahmed N F NEAMAT-ALLAH ${ }^{1}$ \\ \& Hager T.H. ISMAIL ${ }^{1}$ \\ ${ }^{1}$ Clinical Pathology Department, Faculty of Veterinary Medicine, Zagazig University Egypt, Sharkia \\ Province, Zagazig City, 44511 Postal Code, Al Zeraa Street 1 \\ *Corresponding author: drnemovete @yahoo.com
}

Bulletin UASVM Veterinary Medicine 72(2) / 2015,

Print ISSN 1843-5270; Electronic ISSN 1843-5378

DOI:10.15835/buasvmcn-vm: 11208

\begin{abstract}
The present work was performed to study the anticancer effect of doxorubicin HCL and propolis and their combination in the treatment of mammary cancer induced by $\mathrm{N}$-methyl-N-nitrosourea(MNU) beside the ameliorating effect of propolis against side-effects of doxorubicin HCL using the clinicobiochemical and histopathological changes.

One hundred and twenty five female white albino rats (two months old and 100 gm body weight) were divided into five equal groups .Starting of experiment by induction of carcinogen N-methyl-N-nitrosourea (MNU) into gps. (2-5) while rats kept as control in gp.(1). After incidence of mammary tumor in gps. (2-5) begin the treatment which continues for 70 days. Rats were given carcinogen only, doxorubicin HCL, propolis and combination of therapeutic dose from doxorubicin HCL and propolis in gps.(2,3,4 and 5),respectively. Blood samples were collected after 120 days from carcinogen induction and (30 and 70 days) post-treatment. Elevated serum CA 15.3 level in rat gp.(2) injected with carcinogen MNU after 120 days. Serum CA 15.3 showed a significant decrease in gps.(3 and 5) especially 70 days post-treatment.

Results of Gp.(3) showed increasing serum ALT, AST and ALP activities and creatinine and urea level and hepatic (MDA) assay in addition to decrease serum protein and albumin and hepatic (CAT) and (SOD) activities 30 and 70 days post-treatment. These changes were ameliorated in gp.(5). Gp.(4) showed improvement of the previous parameters. Histopathological finding confirm these investigations. So it is concluded that doxorubicin HCL caused hepatic and renal injuries and had cumulative side effects (increasing side effects by increasing intake duration). The propolis did not induce side effects and possessed some anticancer activity but lower than doxorubicin HCL. Combination of doxorubicin HCL with propolis decreased side effects of doxorubicin HCL and increased anticancer activity of the propolis.
\end{abstract}

Keywords: CA 15.3, doxorubicin HCL, Mammary cancer, N-methyl-N-nitrosourea, propolis.

\section{INTRODUCTION}

Cancer is a major burden of disease worldwide (Sutandyo, 2010). Tumor cell invasion of surrounding tissues and distant organs is the primary cause of morbidity and mortality for most cancer cases (Seyfried and Shelton, 2010) . For most primary tumors the treatment of choice is surgery and/or radiotherapy. These measures might be very effective for controlling localized tumors. Systemic chemotherapy with anticancer drugs is required to control outgrowth of metastasis (De Vita, 2001).

Anthracyclines are members of a very important class of antitumor antibiotics that have been used for many years in the treatment of different types of cancer (Temperini et al., 2003). Doxorubicin HCL is first anthracyclines antibiotics and one of the most potent anticancer drugs against 
most animal and human tumors prescribed alone or in combination with other agents which has the widest spectrum of activity (Gruber et al., 2004).

Chemoprevention or chemotherapy via nontoxic agents could be one approach for decreasing the incidence of cancers. Many naturally occurring agents have shown chemopreventive and chemotherapeutic (anticancer) potential in a variety of bioassay systems and animal models (Galati and O'brien, 2004). Propolis has attracted much attention in recent years as a useful or potential agent with application in pharmaceutical products (Valente et al., 2011) . Propolis is a strongly adhesive and resinous substance which collected, transformed and used by bees to seal holes in their honeycombs, smooth out the internal walls and protect the entrance against intruders (Galati and O'brien, 2004). There have been a great number of publications lately considering the antitumor action of propolis and its constituents which indicate their potential for the development of new antitumor agents (Badr et al., 2011b; Kubina et al., 2015).

The aim of the present work is to estimate side effects of doxorubicin HCL and the efficacy of propolis as natural anticancer agent when used alone. The combination of propolis with doxorubicin HCL was also investigated a combination that can counter the side effects of the later. The evaluation included the biochemical and histopathological changes in all rat groups.

\section{MATERIALS AND METHODS}

\section{Animals}

A total of 125 clinically healthy female white albino rats (two months old and 100 gm average body weight) were purchased from the laboratory animal housing of Veterinary Medicine at Zagazig University in Egypt. The animals were kept in metal cages, under hygienic conditions, given balanced ration with water ad-libitum and observed for 10 days before starting of experiment. Experiment was conducted in accordance with the guidelines set by Animal Health Research Ethics Training Initiative, Egypt and experimental protocols were approved by the institutional animal ethics committee.

N-methyl-N-nitrosourea (MNU) was obtained from Sigma-Aldrich, USA as pale yellow crystals or light yellow moist powder. It dissolved in $(0.9 \%) \mathrm{NaCl}$ solution and acidified to $\mathrm{pH}(4)$ with acetic acid within 20 min of preparation (Turcot-Lemay and Kelly, 1980).

Doxorubicin HCL (Adriblastina) was obtained from Pharmacia Italia, Italia as a sterile red-orange lyophilized powder which available in vial .Doxorubicin HCL (10 mg) vial was reconstituted with $5 \mathrm{ml}$ of sodium chloride $(0.9 \%)$ to give a final concentration of $(2 \mathrm{mg} / \mathrm{ml})$ of doxorubicin HCL. After adding the diluent, the vial should be shaken and the contents allowed dissolving.

Propolis was obtained from bee hives located in Sharkia governorate, Egypt as bulk of glue like brownish material resulted from scrapping off the frames of bee hives. Propolis bulk was cut into small pieces and mixed with deionized water and shaked at $95^{\circ} \mathrm{C}$ for 2 hours according to therapeutic dose. Then cooled to room temperature and centrifugated at 1500 r.p.m for 5 minutes to obtain the supernatant (Badr et al., 2011b; Kubina et al., 2015).

\section{Experimental design}

A total of 125 female white albino rats were equally divided into five groups at random (25 rats per group):

Group 1 rats were kept as the negative control group. Group 2 rats were injected intraperitonally with $\mathrm{N}$-methyl-N-nitrosourea at begging of the experiment in (50 mg/kg B.W, a single dose) as a positive control group (Turcot-Lemay and Kelly, 1980). Group 3 rats were treated by doxorubicin HCL via intraperitoneal injection $(10 \mathrm{mg} / \mathrm{kg}$ B.W every 3 weeks) after 120 days of mammary cancer induction by $\mathrm{N}$-methyl-N-nitrosourea injection (Powis, 1983). Group 4 rats were treated by propolis orally (50 mg/kg B.W daily) after 120 days of mammary cancer induction by N-methyl$\mathrm{N}$-nitrosourea injection by using a bent stainless steel stomach tube (Badr et al., 2011b). Group 5 rats were treated by combination of therapeutic dose of doxorubicin HCL and propolis after 120 days of mammary cancer induction by N-methyl$\mathrm{N}$-nitrosourea injection. Treatments were done for 69 days after the occurrence of mammary cancer. The end point of experiment was determined by the spontaneous death of animals.

\section{Serum and tissue sampling}

Rats were sacrificed after they had been anesthetized by ether at 120 days post carcinogen induction and 30 and 70 days post-treatment. Blood samples were collected from the retro- 
orbital venous plexus as five $\mathrm{ml}$ of blood without anticoagulant in a sterile test tube for separation of serum by centrifugation at 3000 r.p.m. /15 minutes. The obtained sera were used to determine total protein (TP), albumin and globulin levels, alanine aminotransferase (ALT), aspartate aminotransferase (AST) and alkaline phosphatase (ALP) activities, creatinine, urea and cancer antigen 15.3 (CA 15.3) levels. Parts of liver were removed by dissection and homogenate for estimation of malondialdhyde (MDA) level and catalase (CAT) and superoxide dismutase (SOD) activities. All biochemical tests were done using test kits of Diamond Egypt, Vitro, Biodiagnostic and Monobind Inc. Small specimens were taken from selected tissue and fixed in 10\% buffered neutral formalin solution, dehydrated in gradual ethanol (70-100\%), cleared in xylene, and embedded in paraffin. Five-micron thickness paraffin sections were prepared and then routinely stained with hematoxylin and eosin (HE) dyes. The sections were mounted with Canada balsam and covered with cover slide to be ready for histopathological examination.

\section{Statistical analysis}

Data obtained from this investigation were analyzed statistically using F-test. Means in the same column followed by different letters were significantly different and the highest value was represented by the letter (a). Tumor marker results after 120 days from carcinogen induction analyzed using T-test (Tamhane and Dunlop, 2000).

\section{RESULTS AND DISCUSSION}

Elevated serum CA 15.3 level (Tab. 1 and 2) was found in breast cancer cases as primary diagnosis. There is a correlation between tumor marker, tumor size and nodal involvement with significantly higher concentrations in cases with larger tumors or in patients with nodal involvement (Czeiger et al., 2014). So its level increased in animals injected with carcinogen after 120 days from induction of cancer as relevant tumor marker for breast cancer. Increasing in serum CA 15.3 level in rats which injected with $\mathrm{N}$-methly-N-nitrosourea alone to induce mammary cancer without treatment may be due to a clear correlation between serum CA 15.3 level and disease progression. Propolis treated group also revealed increasing in serum CA 15.3 level but with lesser degree. The more advanced the disease, the higher the value of serum CA 15.3 (Nieder et al., 2015).Serum CA 15.3 level showed non significant change in groups treated by doxorubicin HCL alone and after combination it with propolis may be due to reduction in serum CA 15.3 level following treatment was a favorable predictive factor for time to disease progression during systemic therapy (Dong et al., 2015) .

Regarding to the histopathological results, mammary glands of rats (Fig.1-9) after onehundred and twenty days from injection with (MNU) showed adenocarcinoma with proliferation of epithelial and stromal components, anastomosing nests of tumor cells with large hyperchromatic nuclei, delicate cytoplasm and numerous mitotic abundant stroma of fibromyoblasts and eosinophilic material in its lumina. Thirty days post-treatment, the mammary glands of rats in gp.(2) showed multifocal lobular adenocarcinoma in the terminal duct and acini with numerous mitoses. Seventy days post-treatment, the mammary glands showed low grade, sclerosing ductal carcinomas and moderated hyperplasia in the lymphocytes of lymphoid follicles. Our results agreed partially with (Golbabapour et al., 2011).

Data presented in this study (Tab. 3 and 4) demonstrated that doxorubicin HCL cause hypoproteinemia and hypoalbuminemia may be due to exposure of the kidneys to drug induced nephrotic syndrome characterized by proteinuria (albuminuria) led to extremely low serum albumin level (Desassis et al., 1997) , which lead to hypoproteinemia (Swift et al., 2003) .Also it may cause the oxidative stress and reduction of protein synthesis in the liver tissue (Boutabet et al., 2011).Combined treated group by doxorubicin HCL and propolis has hypoproteinemia and hypoalbuminemia with lesser in severity than treatment by doxorubicin HCL alone may be due to propolis extract restored the renal functions, prevents renal oxidative stress and reduced the toxic effect of doxorubicin HCL (van Hoesel et al., 1984) .

Hypoalbuminemia was found in rats group which injected with $\mathrm{N}$-methly-N-nitrosourea to induce mammary cancer without treatment may be due to ability of substance to damage liver polyribosomes and protein-soluble factors of the cell sap. The damage may be a consequence of alkylation and carbamoylation of RNA and 
proteins, but the maximal level of methyl groups (70 to 80\%) transferred to polyribosomes is found in RNA (Lerman et al., 1974). Increase in serum globulin level in rats group which injected with $\mathrm{N}$-methly-N-nitrosourea alone to induce mammary cancer without treatment may be due to the association of advancing breast cancer with rises in serum immunoglobulin levels of all major classes suggests a defense reaction against increasing tumor load or secretion immunoglobulin by tumor (Pettingale et al., 1977).

Our study established that doxorubicin HCL increased serum indices of liver function including ALT, AST and ALP activities (Tab. 1 and 2). Increasing in ALT activity may be due to exposure of hepatocytes to doxorubicin HCL result in increase in the formation of oxidative damage (Vanacker et al., 2001). It has been observed that there is an increase in the apoptotic processes in liver tissue after a single dose of doxorubicin HCL (Pedrycz et al., 2005). Doxorubicin HCL in the form of doxorubicin semiquinone has been suggested to play a major role in its hepatotoxic action (Hasinoff and Begleiter, 2006). Semiquinones are unstable under aerobic conditions thereby generating superoxide anion radicals by reacting with molecular oxygen (Lee et al., 1991). Hepatocytes are the likely targets of reactive oxygen species (ROS) attack in the failing liver. It is conceivable that free radicals cause damage at
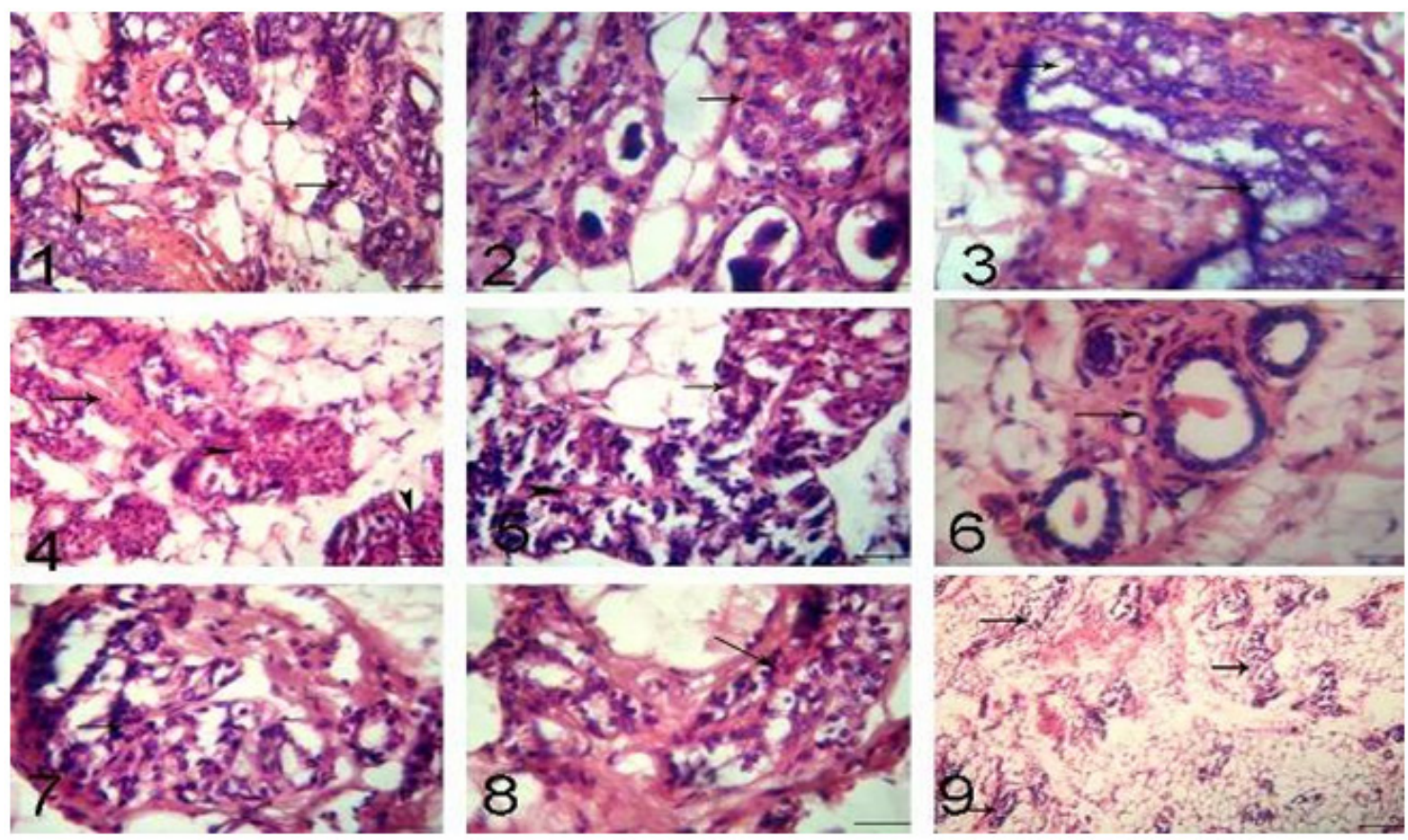

Fig.1. Mammary glands of rat rat showing adenocarcinoma with the proliferation of the epithelial and stromal components. Anastomosing nests of tumor cells with large hyperchromatic nuclei, delicate cytoplasm and numerous mitotic figures were seen (arrows) after one hundred and twenty days from carcinogen (MNU) induction , HE x1200. (2):Mammary glands of rat in gp.(2) showing adenocarcinomas in the terminal duct and acini (arrow) after one hundred and fifty days from carcinogen (MNU) induction , HE x1200 .(3):Mammary glands of rat in gp.(2) showing low grade and sclerosing ductal carcinomas (arrows) after one hundred and ninety days from carcinogen (MNU) induction, HE x1200. (4): Mammary glands of rat in gp.(3) showing adenocarcinoma (arrowheads) and proliferation of stromal tissue (arrow) thirty days post-treatment, HE x1200 .(5): Mammary glands of rat in gp.(3) showing adenocarcinoma (arrow) with scattered areas of necrosis and lymphocytes infiltrations (arrowhead) seventy days post-treatment, HE x1200 .(6): Mammary glands of rat in gp.(4) showing adenocarcinoma in the glandular epithelium of the mammary glands (arrow) thirty days post-treatment, HE x1200. (7): Mammary glands of rat in gp.(4) showing adenocarcinoma with nuclear atypia

and mitoses with mild proliferation of stromal tissue (arrow) seventy days post-treatment, HE x1200. (8):

Mammary glands of rat in gp.(5) showing ductal carcinoma with nuclear atypia and mitoses (arrow) thirty days post-treatment, HE x1200.(9):Mammary glands of rat in gp.(5) showing nests of neoplastic cells. The latter were focally necrotic (arrows) seventy days post-treatment, HE x1200. 
their formation. Consequently, a major source of ROS production, mitochondria could also be major target susceptible to ROS attack (Kalender et al., 2005). While,rats group treated by combination of doxorubicin HCL and propolis showed lower serum ALT activity than rats group treating by doxorubicin HCL alone due to protective effect of flavonoids in propolis by their capacity to capture and to deactivate the free radicals. Also, propolis has a very strong scavenger effect(Li et al., 2008)

Rats group treated by propolis alone showed highly significant decrease in serum ALT activity may be due to propolis ameliorate hepatic dysfunction (Badr et al., 2011a). Its antioxidant properties were considered responsible for preventing the cellular alterations seen in rough endoplasmic reticulum, golgi complex, nucleus and plasma membrane of the hepatocytes (Rodriguez et al., 1997).

Increase in serum ALT activity was found in rats group which injected with $\mathrm{N}$-methly-Nnitrosourea to induce mammary cancer without treatment may be due to the liver is the primary target for carcinogen (N-methyl-N-nitrosourea) and induces multiple cellular, molecular and biochemical change (Pakharukova et al., 2007)

Serum AST and ALP activities increased in all animals groups may be due to the effect of carcinogen as previously mentioned on liver beside possibility of effect of primary mammary tumor itself (Abbasalipourkabir et al., 2010). Serum AST activity used as a marker for liver metastasis in breast cancer patients and also as a marker for hepatotoxicity (Vennila et al., 2006) .Serum ALP activity is a sensitive indicator of mild biliary obstruction, thus being a very sensitive indicator for liver progression, thus it can be used in detecting breast cancer recurrence as ALP activity alone was abnormal in high proportion of breast cancer patients with bone and /or liver metastasis (Keshaviah et al., 2007).

The experimental data also show that effect of doxorubicin HCL on some kidney function tests (Tab. 5 and 6) as serum creatinine level which increased may be due to doxorubicin HCL induce a severe nephrotic syndrome. Several mechanisms have been suggested for its induction to nephrotic syndrome. The most possible mechanisms for their renal toxicity may be alterations of the permeability of the glomerular capillary wall (Weening and Rennke, 1983). Combination treatment by doxorubicin HCL with propolis increase of serum creatinine but with lower value than group treated by doxorubicin HCL alone may be due to caffeic acid phenethyl ester (CAPE) one component of propolis prevented lipid peroxidation and protein oxidation (Badr et al., 2011a) . Also, increasing in serum urea level may be due to renal nephrosis by doxorubicin HCL cause nephron function ceased because of tubule loss before glomerular injury lead to preclude filtration. Also, local extension of glomerular injury to destroy the tubule neck is an important cause of loss of renal function in doxorubicin HCL nephrosis (Javaid et al., 2001). In combined treated group the increase in serum urea lower than group treated by doxorubicin HCL group alone may be due to propolis extract prevents renal oxidative stress induce by doxorubicin HCL by an increasing rate of glutathion (GSH) or by induction of its synthesis or by a scavenger effect (Boutabet et al., 2011) .

Regarding the results (Tab. 7 and 8) of the present study, increasing in hepatic malondialdhyde level in group treated by doxorubicin HCL alone may be due to its quinone group under aerobic conditions can undergo one electron reduction to generate semiquinone radical can rapidly react with oxygen to form superoxide radicals like hydroxyl radical that participate in the peroxidation of membrane lipids leading to increasing malondialdhyde formation .Lipid peroxidation affect liver to a greater extent causing formation of high molecular mass protein aggregates within the membrane. Hence, increase level of malondialdhyde is indicator of lipid peroxidation (Dormandy, 1980) . Coadministration treatment of doxorubicin HCL with propolis decreased malondialdhyde level but not reach to the level of propolis treated group and control group.

Rats group treated by propolis alone has significant decrease in malondialdhyde level may be due to it extracts inhibit lipid peroxidation .This protective effect can be due to scavenging malondialdhyde molecules by propolis active ingredients or by inhibition of mitochondrial and cytosolic lipoperoxydation chain reaction (Wided et al., 2007).Rats group injected by N-methyl-Nnitrosourea without treatment showed increase in malondialdhyde level may be due to alteration in the oxidant -antioxidant profile is known to occur 
in cancer (Yeh et al., 2005). Free radicals are formed in both physiological and pathological conditions in mammalian tissues. Free radicals are capable of altering all major classes of biomolecules, such as lipid, nucleic acid and protein, with changes in their structure and function (Birnboim, 1986).

Concerning the antioxidant enzymes activities in liver, the decrease in catalase activity in doxorubicin HCL treated group may be due to catalase catalyze dismutation of the superoxide anion $\left(\mathrm{O}_{2}^{-}\right)$into hydrogen peroxide $\left(\mathrm{H}_{2} \mathrm{O}_{2}\right)$ which then converting $\mathrm{H}_{2} \mathrm{O}_{2}$ to water thus providing protection against reactive oxygen species (SayedAhmed et al., 2010). The reduction in activity of this enzyme may be caused by the increase in free radical production during doxorubicin HCL metabolism (Danz et al., 2009) . Co-administration of doxorubicin HCL with propolis caused the decrease in catalase activity but with lesser degree than doxorubicin HCL alone treated group may be due to propolis which contain flavonoids increase mitochondrial and cytosolic CAT activity.
The increase in this enzyme activity can be the consequence of an induction of CAT genes and protein expression synthesis (Wided et al., 2007).

Hepatic superoxide dismutase activity increase in propolis group may be due to propolis increase mitochondrial and cytosolic SOD. The increase in this enzymatic activity can be the consequence of an induction in the SOD genes and protein expression synthesis (Wided et al., 2007) . Also, combined treated group with doxorubicin HCL and propolis significantly restored the SOD activity towards normal which indicated that propolis could scavenge reactive free radicals that eventually lessen the oxidative tissue damage and subsequently improved the activity of this antioxidant enzyme (Badr et al., 2011a). While, SOD activity decreased doxorubicin HCL treated group may be due to it undergoes one-electron reduction through a metabolic activation caused by NADPH cytochrome P-450 reductase or other flavin-containing enzymes in microsomes (Bachur et al., 1978).The effect of doxorubicin
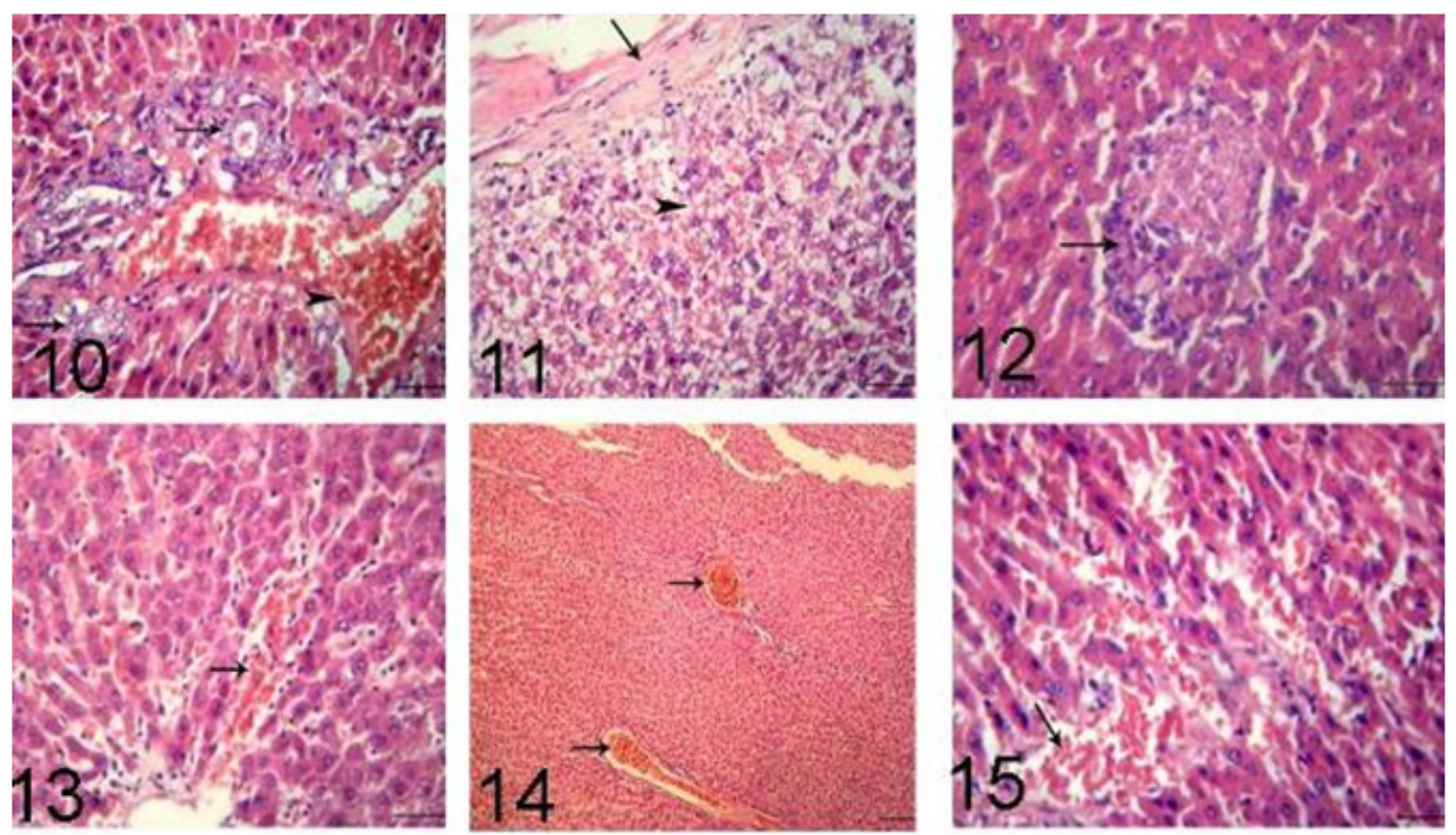

Fig. 10. Liver of rat in gp.(3) showing severe congestion of the portal blood vessels (arrowhead) and hyperplasia in the biliary epithelium (arrows) thirty days post-treatment, HE x1200.(11):Liver of rat in gp.(3) showing thickened capsule with hyalinized fibrous connective tissue (arrow) and subcapsular hydropic degeneration (arrowhead) seventy days post-treatment, HE x1200. (12):Liver of rat in gp.(4) showing necrotic area infiltrated with round cells (arrow) thirty days post-treatment, HE x1200 .(13):Liver of rat in gp.(4) showing few extravasated erythrocytes among the hepatic cells (arrow) seventy days post-treatment, HE x1200. (14):Liver of rat in gp.(5) showing congestion of the portal blood vessels (arrows) thirty days post-treatment, HE x300.

(15):Liver of rat in gp.(5) showing hemorrhage among the hepatocytes (arrow) seventy days post-treatment, HE $\mathrm{x} 1200$. 
HCL on major enzymes participating in free radical metabolism. They found that superoxide dismutase and catalase activities decrease by doxorubicin HCL (Kalender et al., 2005). Also, SOD activity decreased in rats which injected with $\mathrm{N}$-methly-N-nitrosourea alone to induce mammary cancer without treatment may be due to the malignant cells of different cancer types exhibit heterogeneity in the levels of oxidative stress, associated with various expression levels of SOD and other antioxidant enzymes. Decreased SOD activity was observed in various cancerous conditions (Selvendiran et al., 2003) .

Liver histopathology (Fig.10-15) of gp.(3) thirty days post-treatment showed severe congestion of the portal blood vessels and hyperplasia in the biliary epithelium. While, seventy days post-treatment appeared thickened capsule with hyalinized fibrous connective tissue, subcapsular hydropic degeneration and portal aggregations of round cells besides necrotic area .Our results agreed partially with (Rashid et al., 2013).
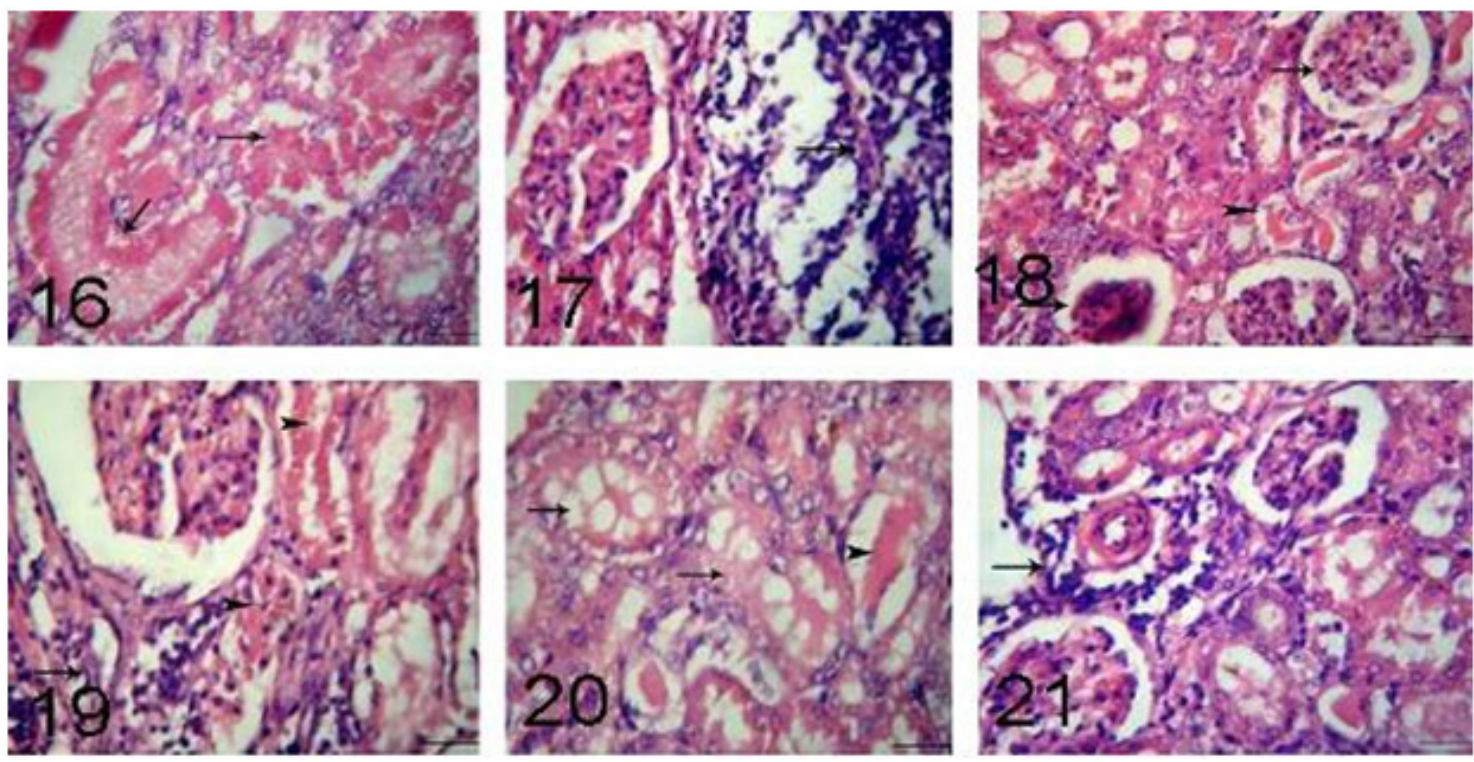

(16):Kidney of rat in gp.(3) showing focal coagulative necrosis and coarse eosinophilic globules in the cortical tubular epithelium (arrows) thirty days post-treatment, HE x1200. (17):Kidney of rat in gp.(3) showing focal interstitial aggregations of round cells (arrow) seventy days post-treatment, HE x1200. (18):Kidney of rat in gp.(4) showing shrunken glomerular tufts (arrow) and hyaline casts inside the renal tubules (arrowheads) thirty days post-treatment, HE x1200. (19):Kidney of rat in gp.(4) showing coagulative necrosis in some tubular epithelia (arrowheads) and few interstitial lymphocytes infiltration (arrow) seventy days post-treatment, HE x1200.(20):Kidney of rat in gp.(5) showing vacuolations of renal tubular epithelia (arrow) and hyaline cast (arrowhead) thirty days post-treatment, HE x1200. (21):Kidney of rat in gp.(5) showing perivascular edema and aggregations of round cells (arrow) seventy days post-treatment, HE x1200. 
Tab. 1. Serum tumor marker (CA 15.3) level (mean values \pm SE) in rats after 120 days from the carcinogen (N-methyl-N nitrosourea ) injection.

\begin{tabular}{ccc}
\hline \multirow{2}{*}{ Parameter } & Gontrol & $\begin{array}{c}\text { MNU (carcinogen) } \\
\text { injected rats }\end{array}$ \\
\cline { 2 - 3 } & $1.88 \pm 0.25$ & $3.38 \pm 0.17$ \\
\hline CA 15.3(U/ml) & \multicolumn{2}{c}{+79.78} \\
\hline \%difference & \\
\hline
\end{tabular}

Tab 2. Serum tumor marker (CA 15.3) level (mean values \pm SE) in rats in gps.(1-5) 30 and 70 days posttreatment.

\begin{tabular}{ccc}
\hline \multirow{2}{*}{ Groups } & \multicolumn{2}{c}{ parameters } \\
\cline { 2 - 3 } & $\begin{array}{c}\text { CA } 15.3(\mathrm{U} / \mathrm{ml}) \\
\text { (After 30 days) }\end{array}$ & $\begin{array}{c}\text { CA 15.3 (U/ml) } \\
\text { (After seventy days) }\end{array}$ \\
\hline Gp.(1) & $1.88^{\mathrm{c}} \pm 0.24$ & $1.28^{\mathrm{c}} \pm 0.16$ \\
\hline Gp.(2) & $3.16^{\mathrm{a}} \pm 0.33$ & $3.80^{\mathrm{a}} \pm 0.49$ \\
\hline Gp.(3) & $2.40^{\mathrm{bc}} \pm 0.12$ & $2.16^{\mathrm{bc}} \pm 0.39$ \\
\hline Gp.(4) & $2.92^{\mathrm{ab}} \pm 0.08$ & $2.84^{\mathrm{ab}} \pm 0.42$ \\
Gp.(5) & $2.28^{\mathrm{bc} \pm 0.21}$ & $1.84^{\mathrm{bc} \pm 0.26}$ \\
F-test & $* *$ & $* *$ \\
\hline
\end{tabular}

Means at the same column followed by different letters were significantly different and the highest value was represented with the letter a. **: Highly significant at 0.01 probability

Gp.(1)Control group,Gp.(2) MNU(carcinogen) , Gp.(3) MNU(carcinogen) +Doxorubicin HCL, Gp.(4) MNU(carcinogen) +Propolis, Gp.(5) MNU(carcinogen) + Doxorubicin HCL +Propolis

Tab. 3. Protein profile \&some liver enzymes (mean values \pm SE) in rats in gps.(1-5) $\mathbf{3 0}$ days post-treatment.

\begin{tabular}{ccccccc}
\hline & \multicolumn{7}{c}{ parameters } \\
\cline { 2 - 7 } Groups & Total protein & Albumin & Globulin & ALT & AST & ALP \\
& $\mathrm{g} / \mathrm{dl}$ & $\mathrm{g} / \mathrm{dl}$ & $\mathrm{g} / \mathrm{dl}$ & $\mathrm{I} / \mathrm{U}$ & $\mathrm{I} / \mathrm{U}$ & $1 / \mathrm{U}$ \\
\hline \multirow{2}{*}{ Gp.(1) } & $5.72^{\mathrm{a}}$ & $3.50^{\mathrm{a}}$ & $2.22^{\mathrm{bc}}$ & $17.96^{\mathrm{d}}$ & $75.80^{\mathrm{d}}$ & $84.99^{\mathrm{d}}$ \\
& \pm 0.23 & \pm 0.07 & \pm 0.20 & \pm 0.88 & \pm 5.38 & \pm 0.83 \\
\hline \multirow{2}{*}{ Gp.(2) } & $5.92^{\mathrm{a}}$ & $3.14^{\mathrm{b}}$ & $2.78^{\mathrm{a}}$ & $22.20^{\mathrm{c}}$ & $133.45^{\mathrm{b}}$ & $126.75^{\mathrm{b}}$ \\
& \pm 0.15 & \pm 0.04 & \pm 0.14 & \pm 0.73 & \pm 1.18 & \pm 1.83 \\
\hline \multirow{2}{*}{ Gp.(3) } & $4.40^{\mathrm{b}}$ & $2.51^{\mathrm{c}}$ & $1.89^{\mathrm{c}}$ & $29.12^{\mathrm{a}}$ & $147.76^{\mathrm{a}}$ & $142.06^{\mathrm{a}}$ \\
& \pm 0.23 & \pm 0.15 & \pm 0.16 & \pm 1.56 & \pm 1.01 & \pm 1.61 \\
\hline \multirow{2}{*}{ Gp.(4) } & $5.68^{\mathrm{a}}$ & $3.26^{\mathrm{ab}}$ & $2.42^{\mathrm{ab}}$ & $16.40^{\mathrm{d}}$ & $123.93^{\mathrm{c}}$ & $120.85^{\mathrm{c}}$ \\
& \pm 0.08 & \pm 0.04 & \pm 0.05 & \pm 0.92 & \pm 1.79 & \pm 1.01 \\
\hline \multirow{2}{*}{ Gp.(5) } & $5.51^{\mathrm{a}}$ & $3.08^{\mathrm{b}}$ & $2.43^{\mathrm{ab}}$ & $25.52^{\mathrm{b}}$ & $130.82^{\mathrm{bc}}$ & $125.46^{\mathrm{b}}$ \\
& \pm 0.14 & \pm 0.08 & \pm 0.11 & \pm 0.33 & \pm 0.80 & \pm 0.59 \\
\hline F-test & $* *$ & $* *$ & $* *$ & $* *$ & $* *$ & $* *$ \\
\hline
\end{tabular}

Means at the same column followed by different letters were significantly different and the highest value was represented with the letter a.

**: Highly significant at 0.01 probability

Gp.(1)Control group, Gp.(2) MNU(carcinogen) , Gp.(3) MNU(carcinogen) +Doxorubicin HCL, Gp.(4) MNU(carcinogen) +Propolis, Gp.(5)

MNU(carcinogen) + Doxorubicin HCL +Propolis 
Tab. 4. Protein profile \&some liver enzymes (mean values \pm SE) in rats in gps.(1-5) 70 days posttreatment.

\begin{tabular}{|c|c|c|c|c|c|c|}
\hline \multirow[b]{2}{*}{ Groups } & \multicolumn{6}{|c|}{ parameters } \\
\hline & $\begin{array}{c}\text { Total protein } \\
\mathrm{g} / \mathrm{dl}\end{array}$ & $\begin{array}{c}\text { Albumin } \\
\mathrm{g} / \mathrm{dl}\end{array}$ & $\begin{array}{c}\text { Globulin } \\
\mathrm{g} / \mathrm{dl}\end{array}$ & $\begin{array}{l}\text { ALT } \\
\text { l/U } \\
\end{array}$ & $\begin{array}{l}\text { AST } \\
\text { l/U } \\
\end{array}$ & $\begin{array}{c}\text { ALP } \\
\text { l/U } \\
\end{array}$ \\
\hline Gp.(1) & $\begin{array}{c}6.19^{\mathrm{a}} \\
\pm 0.17 \\
\end{array}$ & $\begin{array}{c}4.13^{\mathrm{a}} \\
\pm 0.21 \\
\end{array}$ & $\begin{array}{c}2.06 \\
\pm 0.21 \\
\end{array}$ & $\begin{array}{l}17.04^{\mathrm{c}} \\
\pm 0.48 \\
\end{array}$ & $\begin{array}{l}73.00^{c} \\
\pm 3.14 \\
\end{array}$ & $\begin{array}{c}107.56^{\mathrm{d}} \\
\pm 1.85 \\
\end{array}$ \\
\hline Gp.(2) & $\begin{array}{r}6.20^{\mathrm{a}} \\
\pm 0.19 \\
\end{array}$ & $\begin{array}{r}4.09^{a} \\
\pm 0.17 \\
\end{array}$ & $\begin{array}{c}2.11 \\
\pm 0.10 \\
\end{array}$ & $\begin{array}{l}18.71^{c} \\
\pm 0.65 \\
\end{array}$ & $\begin{array}{l}95.80^{\mathrm{b}} \\
\pm 1.98 \\
\end{array}$ & $\begin{array}{c}127.32^{\mathrm{b}} \\
\pm 2.14 \\
\end{array}$ \\
\hline Gp.(3) & $\begin{array}{l}3.87^{c} \\
\pm 0.22 \\
\end{array}$ & $\begin{array}{l}1.37^{c} \\
\pm 0.13 \\
\end{array}$ & $\begin{array}{c}2.50 \\
\pm 0.15 \\
\end{array}$ & $\begin{array}{l}30.67^{\mathrm{a}} \\
\pm 1.19 \\
\end{array}$ & $\begin{array}{l}104.6^{\mathrm{a}} \\
\pm 2.80 \\
\end{array}$ & $\begin{array}{c}166.02^{\mathrm{a}} \\
\pm 1.39 \\
\end{array}$ \\
\hline Gp.(4) & $\begin{array}{r}6.26^{\mathrm{a}} \\
\pm 0.18 \\
\end{array}$ & $\begin{array}{l}3.89^{a} \\
\pm 0.25\end{array}$ & $\begin{array}{c}2.37 \\
\pm 0.08 \\
\end{array}$ & $\begin{array}{l}7.60^{\mathrm{d}} \\
\pm 0.24 \\
\end{array}$ & $\begin{array}{l}95.00^{\mathrm{b}} \\
\pm 1.87\end{array}$ & $\begin{array}{c}115.62^{c} \\
\pm 3.94\end{array}$ \\
\hline Gp.(5) & $\begin{array}{r}4.97^{\mathrm{b}} \\
\pm 0.25 \\
\end{array}$ & $\begin{array}{r}2.52^{\mathrm{b}} \\
\pm 0.21 \\
\end{array}$ & $\begin{array}{r}2.45 \\
\pm 0.16 \\
\end{array}$ & $\begin{array}{l}21.67^{\mathrm{b}} \\
\pm 0.38 \\
\end{array}$ & $\begin{array}{c}100.00^{\mathrm{ab}} \\
\pm 0.63 \\
\end{array}$ & $\begin{array}{c}125.24^{\mathrm{b}} \\
\pm 0.69\end{array}$ \\
\hline F-test & $* *$ & $* *$ & NS & $* *$ & $* *$ & $* *$ \\
\hline
\end{tabular}

Means at the same column followed by different letters were significantly different and the highest value was represented with the letter a. NS:Non significant changes

**: Highly significant at 0.01 probability

Gp.(1)Control group,Gp.(2) MNU(carcinogen) , Gp.(3) MNU(carcinogen) +Doxorubicin HCL, Gp.(4) MNU(carcinogen) +Propolis, Gp.(5) MNU(carcinogen) + Doxorubicin HCL +Propolis

Tab. 5. Some kidney function tests (mean values \pm SE) in rats in gps.(1-5) 30 days post- treatment.

\begin{tabular}{ccc}
\hline \multirow{2}{*}{ Groups } & \multicolumn{2}{c}{ parameters } \\
\cline { 2 - 3 } & Creatinine mg/dl & Urea mg/dl \\
\hline Gp.(1) & $0.52^{\mathrm{b}} \pm 0.007$ & $30.38^{\mathrm{cd}} \pm 0.86$ \\
\hline Gp.(2) & $0.52^{\mathrm{b}} \pm 0.005$ & $28.42^{\mathrm{d}} \pm 1.13$ \\
\hline Gp.(3) & $0.66^{\mathrm{a}} \pm 0.013$ & $41.36^{\mathrm{a}} \pm 0.99$ \\
\hline Gp.(4) & $0.53^{\mathrm{b}} \pm 0.006$ & $32.72^{\mathrm{c}} \pm 0.32$ \\
\hline Gp.(5) & $0.65^{\mathrm{a}} \pm 0.006$ & $35.95^{\mathrm{b}} \pm 1.00$ \\
F-test & $*$ & $*$ \\
\hline
\end{tabular}

Means at the same column followed by different letters were significantly different and the highest value was represented with the letter a. *: significant at 0.05 probability

Gp.(1)Control group,Gp.(2) MNU(carcinogen) , Gp.(3) MNU(carcinogen) +Doxorubicin HCL, Gp.(4) MNU(carcinogen) +Propolis, Gp.(5) MNU(carcinogen) + Doxorubicin HCL +Propolis

Tab. 6. Some kidney function tests (mean values \pm SE) in rats in gps. (1-5) 70 days post- treatment.

\begin{tabular}{ccc}
\hline \multirow{2}{*}{ Groups } & \multicolumn{2}{c}{ parameters } \\
\cline { 2 - 3 } & Creatinine $\mathrm{mg} / \mathrm{dl}$ & Urea $\mathrm{mg} / \mathrm{dl}$ \\
\hline Gp.(1) & $0.46^{\mathrm{c}} \pm 0.011$ & $28.72^{\mathrm{c}} \pm 1.30$ \\
\hline Gp.(2) & $0.49^{\mathrm{c}} \pm 0.009$ & $27.25^{\mathrm{cd}} \pm 0.14$ \\
\hline Gp.(3) & $0.86^{\mathrm{a}} \pm 0.035$ & $73.72^{\mathrm{a}} \pm 1.03$ \\
\hline Gp.(4) & $0.46 \mathrm{c} \pm 0.005$ & $25.86^{\mathrm{d}} \pm 0.56$ \\
\hline Gp.(5) & $0.72^{\mathrm{b}} \pm 0.019$ & $41.77^{\mathrm{b}} \pm 0.99$ \\
F-test & $*$ & $*$ \\
\hline
\end{tabular}

Means at the same column followed by different letters were significantly different and the highest value was represented with the letter a.

**: Highly significant at 0.01 probability

Gp.(1)Control group,Gp.(2) MNU(carcinogen) , Gp.(3) MNU(carcinogen) +Doxorubicin HCL, Gp.(4) MNU(carcinogen) +Propolis, Gp.(5)

MNU(carcinogen) + Doxorubicin HCL + Propolis 
Tab. 7. Hepatic (MDA) level, and (CAT) and (SOD) activities (mean values \pm SE) in rats in gps.(1-5) after 30 days post-treatment.

\begin{tabular}{cccc}
\hline \multirow{2}{*}{ Groups } & \multicolumn{3}{c}{ Parameters } \\
\cline { 2 - 4 } & MDA (nmol/g) & CAT $(\mathrm{U} / \mathrm{g})$ & SOD $(\mathrm{U} / \mathrm{g})$ \\
\hline Gp.(1) & $17.00^{\mathrm{b}} \pm 0.31$ & $15.33^{\mathrm{a}} \pm 0.62$ & $6.18^{\mathrm{b}} \pm 0.18$ \\
Gp.(2) & $17.60^{\mathrm{b}} \pm 0.67$ & $15.33^{\mathrm{a}} \pm 0.81$ & $5.90^{\mathrm{b}} \pm 0.15$ \\
Gp.(3) & $22.66^{\mathrm{a}} \pm 0.81$ & $6.99^{\mathrm{b}} \pm 0.62$ & $5.92^{\mathrm{b}} \pm 0.33$ \\
Gp.(4) & $8.00^{\mathrm{d}} \pm 0.70$ & $16.33^{\mathrm{a}} \pm 0.62$ & $6.91^{\mathrm{a}} \pm 0.15$ \\
Gp.(5) & $11.20^{\mathrm{c}} \pm 0.66$ & $7.99^{\mathrm{b}} \pm 0.33$ & $6.44^{\mathrm{ab}} \pm 0.10$ \\
F-test & $* *$ & $* *$ \\
Means at the same column followed by different letters were significantly different and the highest value was represented with the letter \\
a. ${ }^{* *}$ : Highly significant at 0.01 probability \\
Gp.(1)Control group,Gp.(2) MNU(carcinogen), Gp.(3) MNU(carcinogen) +Doxorubicin HCL, Gp.(4) MNU(carcinogen) +Propolis, Gp.(5) \\
MNU(carcinogen) + Doxorubicin HCL +Propolis
\end{tabular}

Tab. 8. Hepatic (MDA) level, and (CAT) and (SOD) activities (mean values \pm SE) in rats in gps.(1-5) 70 days post-treatment.

\begin{tabular}{cccc}
\hline \multirow{2}{*}{ Groups } & \multicolumn{3}{c}{ Parameters } \\
\cline { 2 - 4 } & $17.20^{\mathrm{b}} \pm 0.48$ & CAT (U/g) & SOD (U/g) \\
\hline Gp.(1) & $20.22^{\mathrm{a}} \pm 0.71$ & $13.99^{\mathrm{a}} \pm 0.40$ & $50^{\mathrm{b}} \pm 0.32$ \\
Gp.(2) & $21.89^{\mathrm{a}} \pm 1.16$ & $13.33^{\mathrm{a}} \pm 0.52$ & $5.00^{\mathrm{c}} \pm 0.28$ \\
Gp.(3) & $5.90^{\mathrm{d}} \pm 0.19$ & $3.66^{\mathrm{c}} \pm 0.33$ & $2.52^{\mathrm{d} \pm 0.12}$ \\
Gp.(4) & $8.55^{\mathrm{c}} \pm 0.67$ & $13.99^{\mathrm{a}} \pm 0.66$ & $7.17^{\mathrm{a}} \pm 0.11$ \\
Gp.(5) & $* * 32^{\mathrm{b}} \pm 0.40$ & $6.60^{\mathrm{a}} \pm 0.16$ \\
F-test & $* *$ & $* *$ \\
\hline Means at the same column followed by different letters were significantly different and the highest value was represented with the letter \\
a. \\
**: Highly significant at 0.01 probability
\end{tabular}

renal injuries and had cumulative side effects (increasing side effects by increasing intake duration). The propolis did not induce side effects and possessed some anticancer activity but lower than doxorubicin HCL. Combination of doxorubicin HCL with propolis decreased side effects of doxorubicin HCL and increased anticancer activity of the propolis. Histopathological finding confirm these investigations.

\section{Acknowledgement}

The authors want to thank Prof. Dr. Mohamed Hamed Mohamed Professor of Pathology Faculty of Veterinary Medicine at Zagazig University for his help in examining and reading histopathological slides.

\section{REFERENCES}

1. Abbasalipourkabir R, Dehghan A, Salehzadeh A , Shamsabadi F , Abdullah R (2010). Induction of mammary gland tumor in female Sprague-Dawley rats with LA7 cells. Afr J Biotech 9: 4491-4498.

2. Bachur NR, Gordon SL, Gee MV(1978). A general mechanism for microsomal activation of quinone anticancer agents to free radicals. Cancer Res 38 (6): 1745-1750.

3. Badr MO, Edrees NM, Abdallah AA, Hashem M, ElDeen NA, Neamat-Allah AN , Ismail HT (2011a). Propolis Protects Against Methotrexate Induced Hepatorenal Dysfunctions during Treatment of Ehrlich Carcinoma. J of AmerSci 7(12): 313-319.

4. Badr MO, Edrees NM, Abdallah AA., El-Deen NA, NeamatAllah AN, Ismail HT (2011b). Anti-tumour effects of Egyptian propolis on Ehrlich ascites carcinoma. Vet Ital 47 (3): 341-350.

5. Birnboim HC (1986). DNA strand breaks in human leukocytes induced by superoxide anion, hydrogen peroxide and tumor promoters are repaired slowly 
compared to breaks induced by ionizing radiation Carcinogenesis 7(9): 1511-1517.

6. Boutabet K, Kebsa W, Alyane M, Lahouel M (2011) Polyphenolic fraction of Algerian propolis protects rat kidney against acute oxidative stress induced by doxorubicin. Indian J Nephrol 21(2):101-106.

7. Czeiger D, Agassi R, Sebbag G, Zlotnik A, Douvdevani A, Shaked G (2014). Plasma DNA measurement as a biomarker of cancer. Harefuah 153 (10): 569-572, 625.

8. Dabak DO, Kuloglu T, Ozercan MR (2009). Effects of vitamin D3 (cholecalciferol) on adriamycin-induced nephrotoxicity. Ren Fail 31(5): 400-405.

9. Danz ED, Skramsted J, Henry N, Bennett JA, Keller RS (2009). Resveratrol prevents doxorubicin cardiotoxicity through mitochondrial stabilization and the Sirt1 pathway. Free Radic Biol Med 46(12):1589-1597.

10. De Vita VT (2001). Principles of chemotherapy, 6th ed. Lippincott Williams and Wilkins Philadelphia, USA.

11. Desassis JF, Raats CJ , Bakker MA., Van den Born J, Berden JH (1997). Antiproteinuric effect of ciclosporin A in adriamycin nephropathy in rats. Nephron 75(3):336341.

12. Dong Y, Hou H, Wang C, Li J, Yao Q, Amer S, Tian M (2015). The Diagnostic Value of (18) F-FDG PET/CT in Association with Serum Tumor Marker Assays in Breast Cancer Recurrence and Metastasis. Biomed Res Int 2015, 5 pages, Article ID 489021.

13. Dormandy TL (1980). Free-radical reaction in biological systems. Ann R Coll Surg Engl 62(3): 188-194.

14. Galati G, O'brien PJ (2004). Serial review: flavonoids and isoflavones (phytoestrogens):absorption,metabolism and bioactivity. Free rad med 37: 287-303.

15. Golbabapour S, Pang W, George J, Pasupati T, AbdulRahman P, Hashim O (2011). Chemically Induced Breast Tumors in Rats Are Detectable in Early Stages by Contrast Enhanced Magnetic Resonance Imaging but Not by Changes in the Acute-Phase Reactants in Serum. Int J Mol Sci 12(2): 1030-1040.

16. Gruber BM, Anuszewska EL, Priebe W (2004). The effect of new anthracycline derivatives on the induction of apoptotic processes in human neoplastic cells. Folia Histochem Cytobiol 42(2): 127-130.

17. Hasinoff BB, Begleiter A (2006). The reductive activation of the antitumor drug RH1 to its semiquinone free radical by NADPH cytochrome P450 reductase and by HCT116 human colon cancer cells. Free Radic Res 40(9): 974-978.

18. Injac R, Boskovic M, Perse M, Koprivec-Furlan E, Cerar A, Djordjevic A, Strukelj B (2008). Acute doxorubicin nephrotoxicity in rats with malignant neoplasm can be successfully treated with fullerenol $\mathrm{C} 60(\mathrm{OH}) 24$ via suppression of oxidative stress. Pharmacol Rep 60(5): 742-749.

19. Javaid B, Olson JL, Meyer TW (2001). Glomerular injury and tubular loss in adriamycin nephrosis. J Am Soc Nephrol 12(7): 1391-1400.

20. Kalender Y, Yel M, Kalender S ( 2005). Doxorubicin hepatotoxicity and hepatic free radical metabolism in rats. The effects of vitamin $\mathrm{E}$ and catechin. Toxicology 209(1):39-45.

21. Keshaviah A, Dellapasqua S, Rotmensz N, Lindtner J, Crivellari D, Collins J, Colleoni M, Thurlimann B, Mendiola C, Aebi S, Price KN, Pagani O, Simoncini E, Castiglione Gertsch M, Gelber RD, Coates AS, Goldhirsch A (2007). CA15-3 and alkaline phosphatase as predictors for breast cancer recurrence: a combined analysis of seven International Breast Cancer Study Group trials. Ann Oncol 18(4):701-708.

22. Kubina R, Kabala-Dzik A, Dziedzic A, Bielec B, Wojtyczka RD, Buldak RJ, Wyszynska M, Stawiarska-Pieta B, Szaflarska-Stojko E (2015). The Ethanol Extract of Polish Propolis Exhibits Anti-Proliferative and/or Pro-Apoptotic Effect on HCT 116 Colon Cancer and Me45 Malignant Melanoma Cells In Vitro Conditions. Adv Clin Exp Med 24(2): 203-212.

23. Lee V, Randhawa AK, Singal PK (1991). Adriamycininduced myocardial dysfunction in vitro is mediated by free radicals. Am J Physiol 261 (4 Pt 2): H989-995.

24. Lerman MI, Abakumova OY, Kucenco NG, Gorbacheva LB, Kukushkina GV, Serebryanyi AM ( 1974). Different degradation rates of alkylated RNA protein and lipids in normal and tumor cells. Cancer Res 34 (7): 1536-1541.

25. Li F, Awale S, Tezuka Y, Kadota S (2008). Cytotoxic constituents from Brazilian red propolis and their structure-activity relationship. Bioorg Med Chem 16(10):5434-5440.

26. Nieder C, Dalhaug A, Haukland E, Mannsaker B, Pawinski A (2015). Tumor marker analyses in patients with brain metastases: patterns of practice and implications for survival prediction research. Tumour Biol 36(8):64716476.

27. Pakharukova MY, Smetanina MA, Kaledin VI, Kobzev VF, Romanova IV, Merkulova TI (2007). Activation of constitutive androstane receptor under the effect of hepatocarcinogenic aminoazo dyes in mouse and rat liver. Bull Exp Biol Med 144(3): 338-341.

28. Pedrycz A, Wieczorski M, Czerny K (2005). Histological and histochemical assessment of the effects of a single dose adriamycin on fetal rat kidney. Acta Histochem 107(3):215-220.

29. Pettingale KW, Merrett TG, Tee DE (1977). Prognostic value of serum levels of immunoglobulins (IgG, IgA, IgM and IgE) in breast cancer: a preliminary study. Br J Cancer 36(5): 550-557.

30. Powis G (1983). Dose-dependent metabolism, therapeutic effect, and toxicity of anticancer drugs in man. Drug Metab Rev 14(6): 1145-1163.

31. Rashid S, Ali N, Nafees S, Ahmad S, Arjumand W, Hasan S, Sultana S (2013). Alleviation of doxorubicin-induced nephrotoxicity and hepatotoxicity by chrysin in Wistar rats. Toxicol Mech Methods 23(5): 337-345.

32. Rodriguez S, Ancheta O, Ramos ME, Remirez D, Rojas E, Gonzalez R (1997). Effects of Cuban red propolis on galactosamine-induced hepatitis in rats. Pharmacol Res, 35(1):1-4

33. Sayed-Ahmed MM, Aleisa AM, Al-Rejaie SS, Al-Yahya AA, AlShabanah OA, Hafez MM, Nagi MN (2010). Thymoquinone 
attenuates diethylnitrosamine induction of hepatic carcinogenesis through antioxidant signaling. Oxid Med Cell Longev 3(4):254-261.

34. Selvendiran K, Singh JP, Krishnan KB, Sakthisekaran D (2003). Cytoprotective effect of piperine against benzo[a] pyrene induced lung cancer with reference to lipid peroxidation and antioxidant system in Swiss albino mice. Fitoterapia 74(1-2): 109-115.

35. Seyfried TN, Shelton LM (2010). Cancer as a metabolic disease.Nutr Metab 7: 7.

36. Sutandyo N (2010). Nutritional carcinogenesis. Acta Med Indones 42(1): 36-42.

37. Swift LP, Cutts SM, Rephaeli A, Nudelman A, Phillips DR (2003). Activation of adriamycin by the $\mathrm{pH}-$ dependent formaldehyde-releasing prodrug hexamethylenetetramine. Mol Cancer Ther 2(2): 189-198.

38. Tamhane A, Dunlop D (2000). Statistic and data analysis from elementary to intermediate. Prentice Hall, Upper Saddle River, New Jersey.USA.

39. Temperini G, Messori L, Orioli P, Bugno C, Animati F, Ughetto G (2003). The crystal structure of the complex between a disaccharide anthracycline and the DNA hexamer d(CGATCG) revealsseventy different binding sites involving seventy DNA duplexes. Nucleic Acids Res 31(5):1464-1469.

40. Turcot-Lemay L, Kelly PA (1980). Characterization of estradiol, progesterone, and prolactin receptors in nitrosomethylurea-induced mammary tumors and effect of antiestrogen treatment on the development and growth of these tumors. Cancer Res 40(9): 3232-3240.
41. Valente MJ, Baltazar AF, Henrique R, Estevinho L, Carvalho M (2011). Biological activities of Portuguese propolis: protection against free radical-induced erythrocyte damage and inhibition of human renal cancer cell growth in vitro. Food Chem Toxicol 49(1):86-92.

42. van Hoesel QG, Steerenberg PA, Vos JG, Hillen FC, Dormans JA (1984). Antitumor effect, cardiotoxicity, and nephrotoxicity of doxorubicin in the IgM solid immunocytoma-bearing LOU/M/WSL rat. J Natl Cancer Inst 72(5):1141-1150.

43. Vanacker H, Lu H, Rate, DN, Greenberg JT (2001). A role for salicylic acid and NPR1 in regulating cell growth in Arabidopsis.Plant J 28 (2):209-216.

44. Vennila R, Thirunavukkarasu SV, Muthumary J (2006). In vivo studies on anticancer activity of Taxol isolated from an endophytic fungus $\mathrm{p}$ estalotiopsis $\mathrm{p}$ auciseta SACC. Asian J Pharml Clinic Res 3(4): 30-34.

45. Weening JJ, Rennke HG (1983). Glomerular permeability and polyanion in adriamycin nephrosis in the rat. Kidney Int 24 (2): 152-159.

46. Wided K, Hassiba R, Nadia B, Lamia B, Mohamed A, Mesbah L ( 2007). Effect of a long term treatment by Algerian propolis flavonoids on mitochondrial antioxidant prooxidant balance. J Pharmacol Drug Res 22: 16-26.

47. Yeh CC, Hou MF, Tsai SM, Lin SK, Hsiao JK, Huang JC, Wang LH, Wu SH, Hou LA, Ma H, Tsai LY ( 2005). Superoxide anion radical, lipid peroxides and antioxidant status in the blood of patients with breast cancer.Clin Chim Acta 361(1-2):104-111. 